\title{
ANALISIS BEBAN KERJA PADA MAINTENANCE BD-CHECK DENGAN METODE FULL TIME EQUIVALENT
}

\author{
Zaskia Azhar Yasmin dan Silvi Ariyanti \\ Program Studi Teknik Industri, Universitas Mercu Buana Jakarta \\ e-mail :_zaskiaazharyasmin@gmail.com
}

\begin{abstract}
ABSTRAK
Dalam suatu perusahaan peran dari karyawan/manpower sangat berpengaruh pada perkembangan perusahaan tersebut. Apabila manpower memiliki kinerja yang baik maka perusahaan akan lebih mudah untuk bergerak maju. Salah satu factor pendukung yang dapat mempengaruhi kinerja daripada manpower adalah bagaimana beban kerja yang diterima oleh manpower tersebut. Oleh karena itu setiap perusahaan membutuhkan adanya perhitungan untuk mengetahui beban kerja yang diterima oleh karyawan nya. Sebagai unit baru, unit TF belum memiliki perhitungan beban kerja dimana unit TF memberlakukan pola kerja 2 shift dan juga sistem lembur yang otomatis. Oleh karena itu unit TF harus segera melakukan perhitungan beban kerja yang diterima oleh para manpower. Tools yang digunakan untuk melakukan perhitungan beban kerja di unit TF adalah dengan menggunakan metode Full Time Equivalent (FTE). Tujuan penelitian ini adalah untuk menghitung beban kerja yang selama ini diterima oleh manpower dan mengetahui kategori dari beban kerja tersebut. Hasil dari penelitian ini berupa perhitungan beban kerja pada unit TF di salah satu kegiatan maintenance yaitu BD-Check dengan beban kerja yang dihasilkan adalah normal dan underload. Berdasarkan hasil analisis diagram sebab akibat serta analisis lebih lanjut menggunakan metode Failure Mode and Effects Analysis (FMEA) faktor terbesar yang menyebabkan kondisi beban kerja underload adalah kurangnya skill dan pengetahuan manpower serta masih terbatasnya ketersediaan tools yang dimiliki oleh unit TF.
\end{abstract}

Kata Kunci: Analisis Beban Kerja, Workload, Full Time Equivalent, Diagram Sebab Akibat, Fishbone, Failure Mode and Effects Analysis

\begin{abstract}
In a company the role of employees / manpower is very influential on the development of the company. If manpower has a good performance, the company will be easier to move forward. One of the supporting factors that can affect the performance of manpower is how the workload is received by the manpower. Therefore, every company needs a calculation to find out the workload received by its employees. As a new unit, the TF unit does not yet have a workload calculation where the TF unit applies a 2 shift work pattern and an automatic overtime system. Therefore the TF unit must immediately calculate the workload received by the manpower. The tools used to calculate workload in TF units are by using the Full Time Equivalent (FTE) method. The purpose of this research is to calculate the workload that has been received by manpower and know the categories of workload. The results of this study in the form of calculation of workload on TF units in one of the maintenance activities, namely BD-Check with the workload produced is normal and underload. Based on the analysis results of cause effect diagram and further analysis using the Failure Mode and Effects Analysis (FMEA) method, the biggest factor causing the underloaded workload conditions was the lack of manpower skills and knowledge and the limited availability of tools owned by the TF unit.
\end{abstract}

Keywords: Workload Analysis Full Time Equivalent, Cause Effect Diagram, Fishbone, Failure Mode and Effects Analysis

\section{PENDAHULUAN}

Dalam pelaksanaannya, perusahaan membutuhkan adanya perhitungan untuk dapat mengetahui berapa besar beban kerja yang diterima oleh karyawan. Apakah dengan manpower yang ada sudah sesuai dan dapat untuk menyelesaikan beban kerja tersebut. Oleh karena itu perusahaan mengharuskan setiap unit kerja untuk dapat melakukan perhitungan terhadap beban kerja yang diterima pada masing-masing unit atau pada masing-masing kegiatan maintenance. Hal tersebut berlaku juga pada unit TF. Unit TF merupakan unit baru dalam perusahaan yakni baru dibentuk pada 
tahun 2016 sehingga unit TF belum memiliki perhitungan aktual terhadap beban kerja.

Pada unit TF, diberlakukan system kerja dengan 2 shift yaitu shift pagi dan shift malam. Dimana untuk 1 kali shift karyawan bekerja selama 12 jam. Dengan sistem kerja 12 jam tersebut maka timbul adanya overtime otomatis sebesar 2 jam perhari, karena para karyawan bekerja diluar batas jam kerja normal (8 jam kerja/hari). Jam kerja 12 jam tersebut dibuat untuk mengantisipasi beban kerja yang tinggi. Oleh karena itu perlu dilakukan penelitian lebih lanjut mengenai perhitungan beban kerja yang diterima oleh karyawan tersebut.

Beban kerja merupakan sejumlah kegiatan yang harus diselesaikan oleh seseorang ataupun suatu organisasi dalam periode tertentu dengan keadan kerja normal [1]. Beban kerja sendiri meliputi dua jenis yaitu beban kerja fisik dan beban kerja mental [2]. Beban kerja fisik bisa ditemui pada pekerjaan-pekerjaan yang lebih memanfaatkan fisik operator dalam menyelesaikan tugasnya, sementara beban kerja mental sering ditemui pada pekerjaan yang memiliki tanggung jawab mental yang besar dalam menjalankan pekerjaanya [3].

FTE terbagi menjadi 3 jenis yaitu overload, normal, dan underload [4]. Berdasarkan pedoman analisis beban kerja yang dikeluarkan oleh Badan Kepegawaian Negara pada tahun 2010, total nilai indeks FTE yang berada di atas nilai 1,28 dianggap overload, berada di antara nilai 1 sampai dengan 1,28 dianggap normal sedangkan jika nilai indeks FTE berada diantara nilai 0 sampai dengan 0,99 dianggap underload atau beban kerjanya masih kurang.

Untuk mendapatkan nilai FTE dari suatu proses kerja adalah sebagai berikut

Total Hours $=$

Frequency $\times$ Process time $\times$ Working days current years 60

Kemudian hasil dari perhitungan total hours sebagai acuan perhitungan FTE dimana:

$F T E=\frac{\text { Total hours }}{\text { Effectivity hours / years }}$
Setelah dihitung beban kerja pada masing-masing jabatan, maka ditentukan penetapan hasil beban kerja dengan menggunakan normal index (normal/ overload/underload). Berikut ini norma index yang digunakan dalam penelitian berdasarkan FTE index yang telah ditentukan oleh perusahaan untuk perhitungan beban kerja, seperti ditunjukkan pada tabel 1 .

Tabel 1 Full Time Equivalent Index

\begin{tabular}{cc}
\hline Hasil Perhitungan Beban Kerja & Kategori \\
\hline $0-0,99$ & Underload \\
$1-1,28$ & Normal \\
$>1,28$ & Overload \\
\hline
\end{tabular}

\section{Menghitung Waktu Siklus, Waktu} Normal dan Waktu Baku

Waktu Normal = Waktu Pengamatan $\times(1+$ Rating Faktor)

Waktu Baku $=$ Waktu Normal $\times \frac{100 \%}{100 \%-\% \text { Allowance }}$

Aktivitas untuk menilai atau mengevaluasi kecepatan kerja operator ini dikenal "Rating Performance". Dengan melakukan rating ini diharapkan waktu kerja yang diukur bisa dinormalkan kembali. Ketidak-normalan dari waktu kerja ini diakibatkan oleh operator bekerja secara kurang wajar yaitu bekerja dalam tempo kecepatan yang tidak sebagaimana mestinya. Suatu saat dirasakan terlalu cepat dan disaat lain malah terlalu lambat. Rating adalah suatu persoalan penilaian yang merupakan bagian dari aktivitas pengukuran kerja dan untuk menetapkan waktu baku penyelesaian kerja maka factor penliaian (lebih cenderung bersifat subyektif) terhadap tempo kerja operator.

Untuk menormalkan waktu kerja yang diperoleh dari hasil pengamatan dan pengukuran, maka hal ini dilakukan dengan mengadakan penyesuaian yaitu dengan cara mengalikan waktu pengamatan rata-rata dengan performance rating. Operator dinyatakan terlalu 
cepat yaitu bekerja diatas batas kewajaran (normal) maka factor penyesuaian akan lebih besar dari pada satu ( $\mathrm{Pf}>1$ atau $\mathrm{Pf}>100 \%)$, operator dinyatakan terlalu lambat yaitu bekerja dengan kecepatan di bawah batas kewajaran (normal) maka faktor penyesuaian ini akan lebih kecil dari pada satu ( $\mathrm{Pf}<1$ atau $\mathrm{Pf}<100 \%)$. Apabila operator bekerja secara normal atau wajar maka factor penyesuaian ini diambil sama dengan satu $(\mathrm{Pf}=1$ atau $\mathrm{Pf}=100 \%)$. Untuk kondisi kerja dimana operasi secara penuh dilaksanakan oleh mesin (operating/machine time) maka waktu yang diukur dianggap merupakan waktu yang normal [5].

Untuk melaksanakan pekerjaan secara normal maka dianggap bahwa operator tersebut cukup berpengalaman pada saat bekerja melaksanakannya tanpa usaha-usaha yang berlebihan sepanjang hari kerja, mnguasai cara kerja yang ditetapkan, dan menunjukkan kesungguhan dalam menjalankan pekerjaannya.

\section{METODOLOGI PENELITIAN}

Penelitian ini merupakan penelitian observasi dengan pendekatan kuantitatif dimana pengumpulan dan pengambilan data dilakukan pada waktu yang bersamaan. Permasalahan pada penelitian ini adalah belum dilakukanya perhitungan dan analisis beban kerja pada unit TF dan adanya kondisi kerja yang overtime. Alur penelitian dengan menggunakan Full Time Equivalent adalah sebagai berikut ;

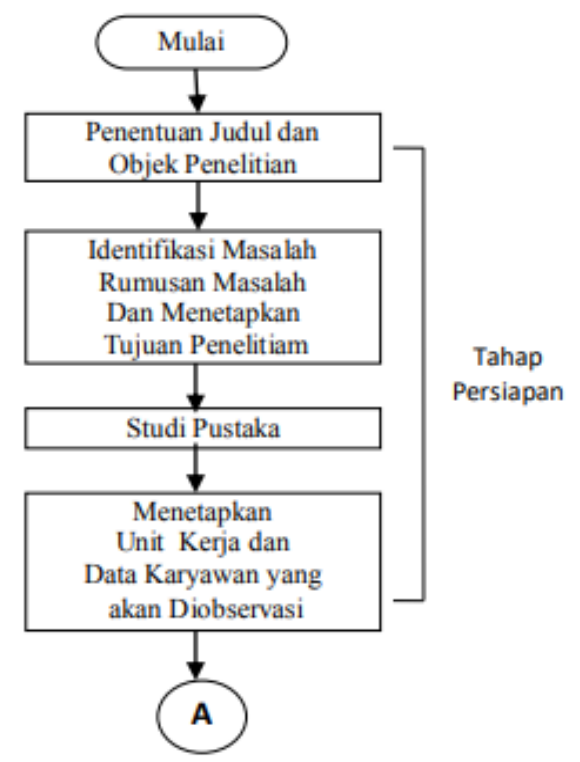

Gambar 1. Langkah-Langkah Penelitian

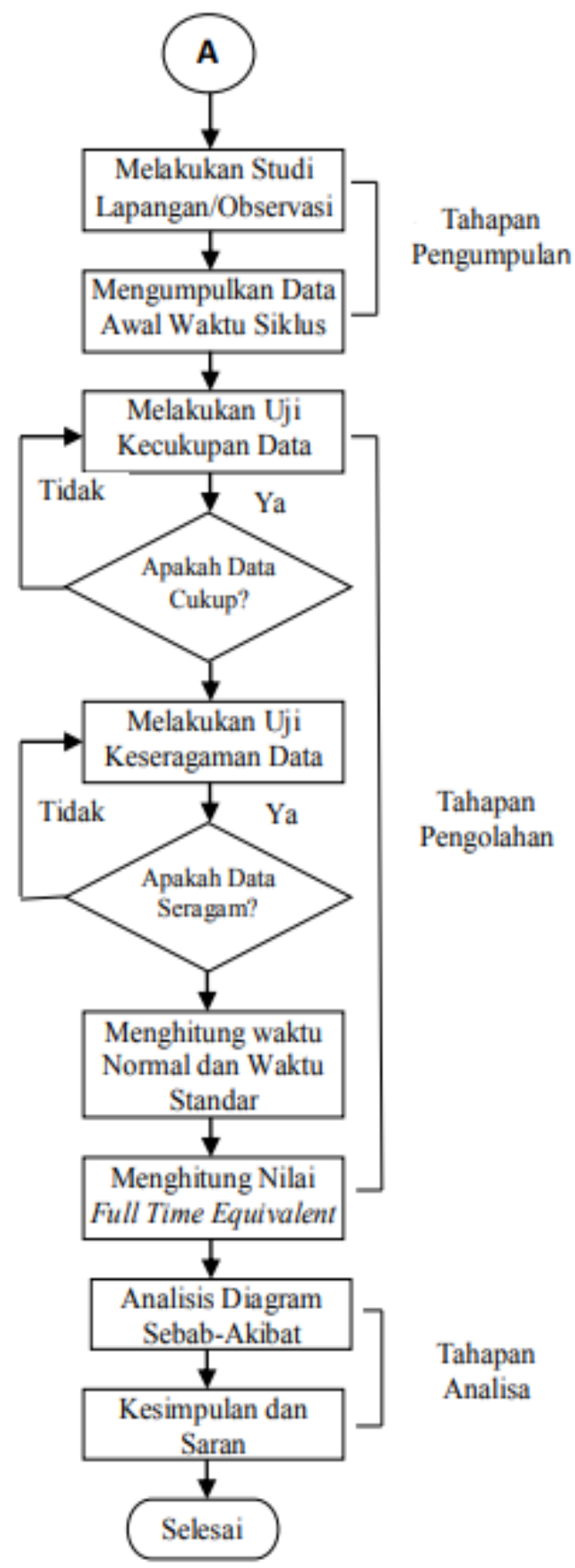

Lanjutan Gambar 1. Langkah-Langkah Penelitian

\section{HASIL DAN PEMBAHASAN Waktu Siklus}

Berdasarkan pengamatan yang dilakukan secara langsung, maka diperoleh waktu siklus pengerjaan maintenance BD-Check pada ke-6 pesawat yang ditunjukkan pada Tabel 2 . 
Tabel 2. Waktu Siklus Pengerjaan Maintenance BD-Check

\begin{tabular}{llcccccc}
\hline Tanggal & Registrasi & \multicolumn{3}{c}{ Waktu Siklus } & \multicolumn{3}{c}{ Waktu Siklus } \\
\cline { 3 - 7 } Pengamatan & Pesawat & Engineer & Mechanic & Total & Engineer & Mechanic & Total \\
\hline 5-May-18 & PK-GMM & $1: 56$ & $3: 05$ & $5: 01$ & 1,93 & 3,08 & 5,02 Jam \\
12-May-18 & PK-GNC & $1: 40$ & $1: 58$ & $3: 38$ & 1,67 & 1,97 & 3,63 Jam \\
7-Apr-18 & PK-GMU & $2: 05$ & $1: 55$ & $4: 00$ & 2,08 & 1,92 & 4,00 Jam \\
14-Apr-18 & PK-GMS & $1: 37$ & $2: 04$ & $3: 41$ & 1,62 & 2,07 & 3,68 Jam \\
21-Apr-18 & PK-GNK & $1: 58$ & $2: 11$ & $4: 09$ & 1,97 & 2,18 & 4,15 Jam \\
28-Apr-18 & PK-GMG & $2: 35$ & $0: 56$ & $3: 31$ & 2,58 & 0,93 & 3,52 Jam \\
\hline & Total & \multicolumn{5}{c}{ Average } & $4: 00$ \\
\hline
\end{tabular}

Tabel 3. Waktu Normal Pengerjaan Maintenance BD-Check

\begin{tabular}{ccccccccc}
\hline \multirow{2}{*}{$\begin{array}{c}\text { Registrasi } \\
\text { Pesawat }\end{array}$} & \multicolumn{3}{c}{ Waktu Siklus } & \multicolumn{3}{c}{$\begin{array}{c}\text { Performance Rate } \\
(\mathrm{PR})\end{array}$} & \multicolumn{3}{c}{ Waktu Normal } \\
\cline { 2 - 9 } & Engineer & Mechanic & Total & Engineer & Mechanic & Engineer & Mechanics & Total \\
\hline PK-GMM & 1,93 & 3,08 & 5,02 & 0,07 & 0,07 & 2,07 & 3,3 & 5,37 \\
PK-GNC & 1,67 & 1,97 & 3,63 & 0,28 & 0,28 & 2,13 & 2,52 & 4,65 \\
PK-GMU & 2,08 & 1,92 & 4 & 0,28 & 0,25 & 2,67 & 2,4 & 5,06 \\
PK-GMS & 1,62 & 2,07 & 3,68 & 0,28 & 0,28 & 2,07 & 2,65 & 4,71 \\
PK-GNK & 1,97 & 2,18 & 4,15 & 0,19 & 0,19 & 2,34 & 2,6 & 4,94 \\
PK-GMG & 2,58 & 0,93 & 3,52 & 0,22 & 0,09 & 3,15 & 1,02 & 4,17 \\
\hline Total & \multicolumn{7}{c}{4} \\
\hline
\end{tabular}

Data waktu siklus kemudian dilakukan pengujian kecukupan dan keseragaman data, dari hasil perhitungan diperoleh data yang digunakan cukup dan seragam sehingga bisa dilanjutkan ke tahap selanjutnya yaitu menentukan waktu normal

\section{Waktu Normal}

Waktu normal merupakan waktu kerja yang telah mempertimbangkan adanya faktor penyesuaian/rating factor. Penentuan rating factor dalam penelitian ini menggunakan metode westinghouse, dimana pemberian nilai rating factor berdasarkan 4 kategori yaitu; kemampuan dalam melakukan maintenance (skill), usaha yang dikeluarkan dalam mengerjakan pekerjaan (effort), kondisi fisik lingkungan seperti keadaan pencahayaan, temperature dan kebisingan ruangan (conditions) serta konsistensi dalam bekerja (consistency), sehingga waktu normal bisa diperoleh dari hasil perkalian waktu siklus dan rating factor. Hasil perhitungan waktu normal ditunjukkan pada Tabel 3.

\section{Waktu Baku}

Dengan diketahui nilai waktu normal pada pengerjaan maintenance di masing-masing pesawat, maka dapat ditentukan waktu baku/ waktu standar yaitu waktu yang sebenarnya digunakan oleh manpower untuk melakukan 1 kali kegiatan maintenance. Perhitungan waktu baku dengan mempertimbangkan adanya faktor kelonggaran/faktor allowance yang dibutuhkan/ yang digunakan oleh manpower dapat dilihat pada Tabel 4.

Tabel 4. Waktu Baku Pengerjaan Maintenance

\begin{tabular}{ccccc}
\hline \multirow{2}{*}{$\begin{array}{c}\text { Registrasi } \\
\text { Pesawat }\end{array}$} & \multicolumn{3}{c}{ Waktu Normal } & \multirow{2}{*}{ WB } \\
\cline { 2 - 4 } & Engineer & Mechanics & Total & \\
\hline PK-GMM & 2 & 3 & 5,37 & 5,9 \\
PK-GNC & 2 & 3 & 4,65 & 5,12 \\
PK-GMU & 3 & 2 & 5,06 & 5,57 \\
PK-GMS & 2 & 3 & 4,71 & 5,19 \\
PK-GNK & 2 & 3 & 4,94 & 5,43 \\
PK-GMG & 3 & 1 & 4,17 & 4,59 \\
\hline Total & & & 4,82 & 5,3 \\
\hline
\end{tabular}

\section{Perhitungan Full Time Equivalent}

Perhitungan beban kerja yang digunakan dalam penelitian ini adalah metode Full Time Equivalent (FTE), dimana perhitungan yang digunakan berdasarkan waktu untuk menyelesaikan pekerjaan maintenance dibandingkan dengan waktu kerja efektif yang tersedia. Untuk dapat melakukan perhitungan nilai Full Time Equivalent perlu terlebih dahulu mengetahui frekuensi daripada pengerjaan maintenance BD-Check dalam 1 hari, lama 
waktu proses penyelesaian maintenance dan jumlah jam kerja manpower dalam 1 tahun. Dalam penelitian ini frekuensi pengerjaan BDCheck dalam 1 hari kurang lebih sebanyak 135 kali. Waktu kerja manpower dengan pola kerja shift 2 hari kerja dan 2 hari Off selama 1 tahun adalah sebanyak 171 hari. Dan waktu kerja efektif manpower dalam 1 tahun adalah sebanyak 1846,8 jam. Setelah mendapatkan nilai dari total hours, maka nilai Full Time Equivalent dapat diperoleh dari rasio antara total jam kerja dalam 1 tahun dengan waktu kerja efektif dalam 1 tahun, seperti terlihat pada Tabel 5 [5][7][8][9].

\section{Analisis Sebab Akibat (Diagram Fishbone)}

Dari ke-6 pengerjaan jenis maintenance yang sama, dengan elemen kerja utama dan job description yang serupa terjadi perbedaan adanya kategori beban kerja. Yaitu terdapat pengerjaan maintenance BD-Check dengan beban kerja normal/beban kerja yang telah sesuai dengan manpower yang ada dan terdapat juga pengerjaan maintenance BD-Check dengan beban kerja yang diterima mainpower adalah underload/kurangnya beban kerja. Hal tersebut dapat disebabkan karena adanya beberapa faktor yang diuraikan dengan menggunakan diagram fishbone seperti ditunjukkan pada Gambar 2.

\section{Failure Mode Effect Analysia (FMEA)}

Berdasarkan hasil analisis diagram dengan metode fishbone diagram tersebut di atas terdapat 6 faktor yang mempengaruhi adanya beban kerja yang underload. Dari faktor tersebut kemudian dilakukan analisis lebih lanjut menggunakan metode FMEA (Failure Mode and Effect Analysis) untuk dapat mengetahui faktor penyebab dengan potensi terbesar yang menimbulkan adanya beban kerja underload. Berdasarkan hasil analisis dengan menggunakan metode FMEA diketahui adanya beban kerja underload mayoritas disebabkan oleh faktor manusia dan tools. Maka factor yang dapat dilakukan usulan perbaikan pada unit TF adalah dengan meningkatkan skill yang dimiliki oleh manpower dan juga melakukan pengadaan tools pada tools store di unit TF [10][11], seperti ditunjukkan pada Tabel 7.

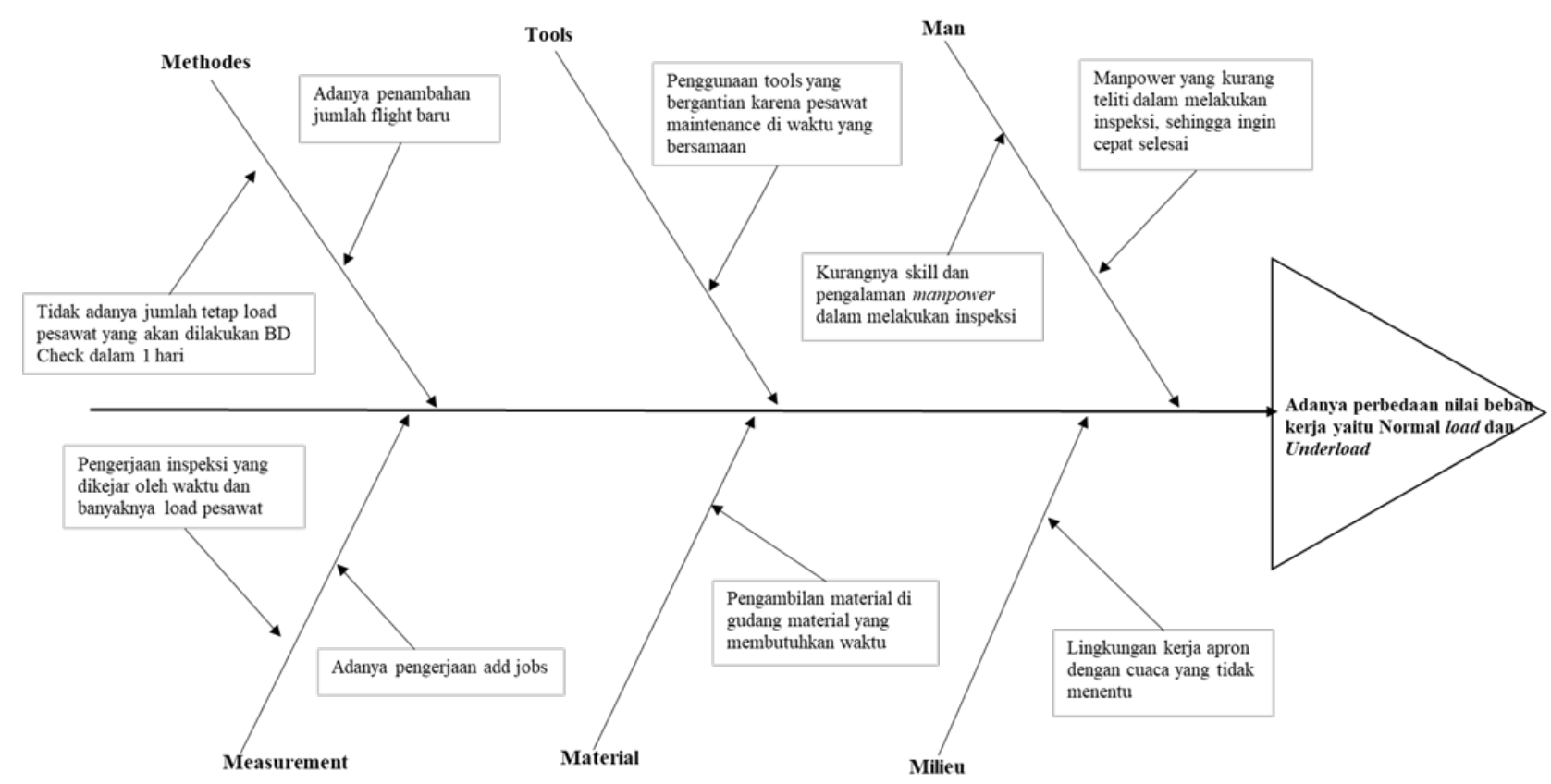

Gambar 2. Diagram Sebab Akibat Beban Kerja Underload 
Tabel 5. Hasil Perhitungan Full Time Equivalent Pekerjaan Maintenance BD Check

\begin{tabular}{ccrrrrrrrr}
\hline $\begin{array}{c}\text { Registrasi } \\
\text { Pesawat }\end{array}$ & Intensitas Frekuensi & $\begin{array}{c}\text { Waktu } \\
\text { Normal }\end{array}$ & \multicolumn{2}{c}{$\begin{array}{l}\text { Jumlah hari } \\
\text { kerja/Tahun (hours/year) }\end{array}$} & $\begin{array}{c}\text { Totfective } \\
\text { horking } \\
\text { hours/year }\end{array}$ & FTE & $\begin{array}{r}\text { FTE } \\
\text { Normal }\end{array}$ & $\begin{array}{c}\text { Kategori } \\
\text { Beban } \\
\text { Kerja }\end{array}$ \\
\hline PK-GMM & Harian & 135 & 5,37 & 171 & 2066,1075 & 1846,8 & 1,11875 & $1,0-1,28$ & Normal/Fit \\
PK-GNC & Harian & 135 & 4,65 & 171 & 1789,0875 & 1846,8 & 0,96875 & $1,0-1,28$ & Underload \\
PK-GMU & Harian & 135 & 5,06 & 171 & 1946,835 & 1846,8 & 1,054167 & $1,0-1,28$ & Normal/Fit \\
PK-GMS & Harian & 135 & 4,71 & 171 & 1812,1725 & 1846,8 & 0,98125 & $1,0-1,28$ & Underload \\
PK-GNK & Harian & 135 & 4,94 & 171 & 1900,665 & 1846,8 & 1,029167 & $1,0-1,28$ & Normal/Fit \\
PK-GMG & Harian & 135 & 4,17 & 171 & 1604,4075 & 1846,8 & 0,86875 & $1,0-1,28$ & Underload \\
\hline
\end{tabular}

Tabel 6. Failure Mode Effect Analysis (FMEA)

\begin{tabular}{|c|c|c|c|c|c|c|c|c|}
\hline No & $\begin{array}{c}\text { Mode } \\
\text { Kegagalan }\end{array}$ & $\begin{array}{c}\text { Potensi Efek } \\
\text { Kegagalan }\end{array}$ & S & $\begin{array}{l}\text { Penyebab Potensi } \\
\text { Kegagalan }\end{array}$ & $\mathrm{O}$ & $\begin{array}{c}\text { Proses Kontrol Saat } \\
\text { Ini }\end{array}$ & $\mathrm{D}$ & RPN \\
\hline 1 & $\begin{array}{l}\text { Kurangnya skill } \\
\text { dan } \\
\text { pengetahuan } \\
\text { dalam inspeksi }\end{array}$ & $\begin{array}{l}\text { Adanya Item } \\
\text { inspeksi yang } \\
\text { ditunda untuk } \\
\text { dilakukan }\end{array}$ & 6 & $\begin{array}{l}\text { Banyaknya } \\
\text { manpower yang } \\
\text { belum mendapatkan } \\
\text { training } \\
\text { Pelaksanaan training } \\
\text { yang mengantri } \\
\text { dengan unit lain } \\
\end{array}$ & 8 & $\begin{array}{l}\text { Dalam melakukan } \\
\text { maintenance, } \\
\text { mekanik yang baru } \\
\text { akan bekerja secara } \\
\text { under supervisor }\end{array}$ & 5 & 280 \\
\hline 2 & $\begin{array}{l}\text { Kurangnya } \\
\text { ketelitian dalam } \\
\text { melakukan } \\
\text { inspeksi }\end{array}$ & $\begin{array}{l}\text { Adanya Item } \\
\text { inspeksi yang tidak } \\
\text { dilakukan }\end{array}$ & 6 & $\begin{array}{l}\text { Mempercepat } \\
\text { pengerjaan } \\
\text { maintenance karena } \\
\text { mengejar load baru } \\
\text { yang akan masuk }\end{array}$ & 3 & $\begin{array}{l}\text { Dilakukannya } \\
\text { pengawasan } \\
\text { langsung pada saat } \\
\text { maintenance oleh } \\
\text { pihak Quality } \\
\text { Control } \\
\end{array}$ & 5 & 90 \\
\hline
\end{tabular}

\begin{tabular}{|c|c|c|c|c|c|c|c|c|}
\hline 3 & $\begin{array}{l}\text { Ketersediaan } \\
\text { tools yang } \\
\text { kurang } \\
\text { memadai }\end{array}$ & $\begin{array}{l}\text {-Menimbulkan } \\
\text { adanya waktu } \\
\text { menunggu tools } \\
\text { pada maintenance } \\
\text { yang sedang } \\
\text { dilakukan di } \\
\text { pesawat lain } \\
\text {-Waktu pengerjaan } \\
\text { maintenance yang } \\
\text { lebih lama }\end{array}$ & 4 & $\begin{array}{l}\text { Tools yang dimiliki } \\
\text { oleh unit TF masih } \\
\text { terbatas } \\
\text { Pemakaian tools } \\
\text { yang bergantian }\end{array}$ & 8 & $\begin{array}{l}\text { Mengontrol keluar } \\
\text { masuknya } \\
\text { penggunaan tools }\end{array}$ & 5 & 160 \\
\hline 4 & $\begin{array}{l}\text { Terus terjadinya } \\
\text { penambahan } \\
\text { jumlah flight }\end{array}$ & $\begin{array}{l}\text { - load maintenance } \\
\text { yang ditimbulkan } \\
\text { akan semakin } \\
\text { bertambah } \\
\text { - Adanya Item } \\
\text { inspeksi yang } \\
\text { ditunda untuk } \\
\text { dilakukan }\end{array}$ & 4 & $\begin{array}{l}\text { Adanya penambahan } \\
\text { rute penerbangan } \\
\text { yang dilakukan oleh } \\
\text { customer perusahaan }\end{array}$ & 5 & $\begin{array}{l}\text { Mengontrol } \\
\text { penambahan jumlah } \\
\text { flight dari customer } \\
\text { agar masih dalam } \\
\text { batas kemampuan } \\
\text { pesrusahaan }\end{array}$ & 4 & 80 \\
\hline 5 & $\begin{array}{l}\text { Perubahan } \\
\text { jumlah load }\end{array}$ & $\begin{array}{l}\text { Beban kerja yang } \\
\text { diterima oleh } \\
\text { manpower tidak } \\
\text { tetap }\end{array}$ & 2 & $\begin{array}{l}\text { Adanya jadwal rute } \\
\text { penerbangan yang } \\
\text { tidak memiliki waktu } \\
\text { tetap pada setiap hari } \\
\text { Adanya faktor cuaca } \\
\text { yang dapat } \\
\text { mengakibatkan } \\
\text { schedule pesawat } \\
\text { menjadi berubah }\end{array}$ & 7 & $\begin{array}{l}\text { Dilakukan } \\
\text { pengontrolan flight } \\
\text { schedule dan } \\
\text { maintenance } \\
\text { schedule oleh unit } \\
\text { MCC (Maintenance } \\
\text { Control Center) } \\
\text { setiap hari }\end{array}$ & 2 & 28 \\
\hline
\end{tabular}


Lanjutan Tabel 6. Failure Mode Effect Analysis (FMEA)

\begin{tabular}{|c|c|c|c|c|c|c|c|c|}
\hline No & $\begin{array}{c}\text { Mode } \\
\text { Kegagalan }\end{array}$ & $\begin{array}{l}\text { Potensi Efek } \\
\text { Kegagalan }\end{array}$ & S & $\begin{array}{l}\text { Penyebab Potensi } \\
\text { Kegagalan }\end{array}$ & $\mathrm{O}$ & $\begin{array}{c}\text { Proses Kontrol Saat } \\
\text { Ini }\end{array}$ & D & RPN \\
\hline 6 & $\begin{array}{l}\text { Pengerjaan add } \\
\text { jobs }\end{array}$ & $\begin{array}{l}\text { Menyebabkan } \\
\text { proses maintenance } \\
\text { pesawat menjadi } \\
\text { lebih lama. } \\
\text { Mengakibatkan } \\
\text { waktu tunggu pada } \\
\text { maintenance } \\
\text { pesawat lainnya }\end{array}$ & 2 & $\begin{array}{l}\text { Adanya kondisi } \\
\text { abnormal pada } \\
\text { pesawat tersebut } \\
\text { sehingga harus } \\
\text { dilakukan pengerjaan } \\
\text { add jobs }\end{array}$ & 5 & $\begin{array}{l}\text { Dilakukan } \\
\text { pengontrolan } \\
\text { adanya pengerjaan } \\
\text { add jobs setiap hari }\end{array}$ & 4 & 40 \\
\hline 7 & $\begin{array}{l}\text { Letak lokasi } \\
\text { pengambilan } \\
\text { material yang } \\
\text { membutuhkan } \\
\text { waktu }\end{array}$ & $\begin{array}{l}\text { Menimbulkan } \\
\text { adanya waktu } \\
\text { menunggu } \\
\text {-Waktu pengerjaan } \\
\text { maintenance } \\
\text { menjadi lebih lama }\end{array}$ & 2 & $\begin{array}{l}\text { Area tempat parkir } \\
\text { pesawat yang luas } \\
\text { dan tidak menetap }\end{array}$ & 9 & $\begin{array}{l}\text { Menggunakan } \\
\text { transportasi mobil } \\
\text { material handling } \\
\text { untuk } \\
\text { mengakomodir } \\
\text { jarak tersebut }\end{array}$ & 4 & 72 \\
\hline 8 & Cuaca & $\begin{array}{l}\text { Penundaan } \\
\text { pelaksanaan waktu } \\
\text { maintenance } \\
\text { Waktu pengerjaan } \\
\text { maintenance } \\
\text { menjadi lebih lama }\end{array}$ & 2 & $\begin{array}{l}\text { Area kerja } \\
\text { maintenance yang } \\
\text { banyak dilakukan di } \\
\text { apron }\end{array}$ & 9 & $\begin{array}{l}\text { Untuk maintenance } \\
\text { yang berat } \\
\text { dilakukan di dalam } \\
\text { hangar }\end{array}$ & 4 & 72 \\
\hline
\end{tabular}

\section{KESIMPULAN}

Berdasarkan penelitian yang telah dilakukan, maka disimpulkan bahwa kegiatan maintenance BD-Check yang dilakukan pada pesawat yang berbeda, terdapat perbedaan kategori beban kerja yang diterima oleh manpower. Dari ke-6 pengamatan pada pesawat tersebut, 3 diantara pengerjaan maintenance BD-Check memiliki beban kerja yang cukup / normal dan 3 pesawat lainnya dengan beban kerja underload/kurangnya beban kerja. Pengerjaan maintenance BD-Check beban kerja underload disebabkan oleh kurangnya kemampuan manpower dalam melakukan inspeksi, kurangnya ketersediaan tools, pengerjaan inspeksi yang dikejar oleh waktu dan banyaknya load pesawat, sehingga usulan perbaikan berupa training pengadaan tools pada unit TF perlu dilakukan, untuk mengurangi adanya kondisi beban kerja yang overload

\section{DAFTAR PUSTAKA}

[1] Hermanto. 2011. Pengaruh Tim Kerja dan Beban KerjaTerhadap Kinerja Karyawan Pada PT. Areowisata Catering Service Di Surabaya. Jurnal FE Manajemen. Surabaya: Universitas Bhayangkara.
[2] Manuaba. 2000. Hubungan Beban Kerja Dan Kapasitas Kerja. Jakarta: Rinek Cipta.

[3] Adipradana. 2008. Analysis Beban Kerja. Diakses pada http://adipradana.wordpress.com.

[4] Karo, Gidion dan Erwin Adianto. 2014. Pengukuran Produktivitas Karyawan Dengan Metode Full Time Equivalent (FTE) PT. Astra International Tbk Divisi Astra Motor Penempatan Jakarta Honda Center. Journal of Industrial Engineering \& Management System Vol. 7, No. 1.

[5] Ghantar, Muhammad. 2017. Efektivitas Manpower Planning Dengan Menggunakan Metode Analisis Beban Kerja (Work Load Analysis) Berdasarkan Pendekatan Full Time Equivalent (Studi Pada Divisi Pengembangan Karir, Organisasi, dan Kompetensi di PT Pupuk Kalimantan Timur Tbk Bontang, Kalimantan Timur). Malang : Universitas Brawijaya

[6] Wiignjosoebroto S. 2008. Ergonomi Studi Gerak dan Waktu. Surabaya: Guna Wijaya.

[7] Dewi, U dan Satrya, A. 2012. Analisis Kebutuhan Tenaga Kerja Berdasarkan 
Beban Kerja Karyawan Pada PT PLN (Persero) Distribusi Jakarta Raya dan Tangerang Bidang Sumber Daya Manusia dan Organisasi. Jakarta: Universitas Indonesia.

[8] Adawiyah, W. 2013. Analisis Beban Kerja Sumber Daya Manusia Dalam Aktivitas Produksi Komoditi Sayuran Selada (Studi Kasus: CV Spirit Wira Utama). Bogor: Fakultas Ekonomi dan Manajemen Institut Pertanian Bogor.
[9] Zimmerman, P.G. 2002. Nursing Management Secrets. United Kingdom: Elsevier Health Sciences.

[10] Chrysler, L.L.C. 2008. Potential Failure Mode And Effects Analysis (FMEA). United States: Ford Motor Company, General Motors Corporation.

[11] McDermott, E.R. 2009. The Basic of FMEA, Edisi 2. USA : CRC Press 